Research Council of Canada from May 1932 until March 1937.

Of his work at Manitoba, Mr. Sidney Smith, who has just retired from the post of president of the University of Manitoba, says : "Dr. Frank Allen was a pioneer and a builder in the first university in Western Canada-the University of Manitoba. Appointed to the staff of that University in 1904, when it became a teaching institution, he founded the Department of Physics, of which for forty years he has been the distinguished head. As a gifted teacher, his record may be read in the careers of generations of students. To the new university he brought an inquiring mind and the spirit of research. He constantly advocated that a university is charged with the responsibility of conserving and transmitting the wisdom and culture of the past and also with the duty of extending the horizons of knowledge. $\mathrm{He}$ always considered physics in relation to the other physical sciences and, in fact, as a part of a truly liberal education. Specialization did not narrow his outlook : it broadened his interests and influence".

Prof. Allen's research work has been almost entirely on the rather dim borderland where physics, physiology and psychology, the 'three p's', meet. His first work was on colour vision. His aim was to investigate the nervous actions underlying colour vision and other sensory activities. In his own words, the aim of his work was first to place the sense of colour vision on a foundation of experimentally ascertained physiological principles, and then to establish the fundamental identity of the processes underlying all of the special senses, including vision, hearing, taste and touch. Prof. Allen is now engaged on collecting the results of his life-work; many of his papers have appeared in scientific journals, particularly the Transactions of the Royal Society of Canada. Prof. Allen's wife died some years ago, but he has a family of two sons and one daughter-Dr. J. F. Allen, who has just been elected to a fellowship at St. John's College, Cambridge; William Allen, an architect in London (England); and Miss Lillian Allen, on the staff of the University of Manitoba. Prof. Allen's many friends join in wishing him many happy years of useful work.

\section{Chair of Psychology, Birkbeck College}

Dr. C. A. Mace, who has been appointed to the chair of psychology at Birkbeck College, University of London, holds the degrees of M.A. Cambridge and D.Litt. London. After leaving Cambridge he was for a time at University College, Nottingham. From there he was appointed lecturer in logic and psychology in the University of St. Andrews. He left Scotland to take up the position of University reader in psychology at Bedford College, London. Dr. Mace has published books and papers in both psychology and philosophy, his best-known work in philosophy being the "Principles of Logic" (1933). In psychology his interests are mainly in social and industrial spheres, and in problems concerning economical methods in learning. In 1935 he published a monograph "Incentives, some Experimental Studies" (Ind. Health Res. Bd. Report No. 72). This was mainly concerned with problems arising in industry owing to variations in the will to work of the employee in contrast to the more usual studies of ability. Dr. Mace has also worked on the fluctuations of interests of college and Workers' Educational Association students over several years, and on the psycho- logical make-up of groups of friends. His latest publication is a paper in the Sociological Review on some of the psychological causes of national prejudice. In this paper he makes an important theoretical distinction between stereotypes, or rigid mechanisms of thought, and plastotypes, or more fluid ones. Dr. Mace has always been keenly interested in adult education, so his appointment to Birkbeck College seems a singularly happy choice.

\section{Book Production}

Is connexion with the recent discussion of the shortage of educational and other books (see Nature, September 9, p. 319), the following reply given by Mr. Dalton in the House of Commons on September 26 should be noted: "The Minister of Production has agreed, at my request, to increase the allocation of paper to publishers of books as from the end of next month to $42 \frac{1}{2}$ per cent of their pre-war usage. I hope that the publishers will do all they can to devote this extra paper to supplying liberated territories, as well as Empire and other oversea markets. The Minister of Production has also increased by more than one third the allocation to my special reserve, and has made a further additional allocation for certain classes of educational books. I am in touch with the Minister of Labour about the supply of labour for printing and binding." The additional allowance of $2 \frac{1}{2}$ per cent of publishers' 1938-39 consumption of paper will be welcome; but it is difficult to see how Mr. Dalton's hope that the extra paper should be used to supply liberated territories and overseas markets could be fulfilled. It seems very doubtful if any publisher would be able to differentiate sharply between books for such overseas markets and those for use in Great Britain. In any event, there is a definite shortage of educational and scientific books, which are needed as much at home as abroad. Publishers are well aware of this, and will no doubt do all in their power to overcome it. They. will also note Mr. Dalton's remark that he is in touch with the Minister of Labour about the supply of labour in the printing and binding trades. As we have said before, these trades have been stripped of labour, and until more workpeople are made available, full use cannot be made of the additional allocation of paper for the production of educational and other books.

\section{Practical Limits in Social Reform}

Bullerin No. 5 of the Tory Reform Committee "What Shall We Use for Money.?" is of interest as an attempt to indicate the broad limits of what is politically and economically practicable in the field of social reform. The pamphlet distinguishes between income and outlay of the nation as a whole, and the Exchequer aspect, or that part of the national income which passes through the Revenue and Expenditure of the Exchequer. These aspects are discussed separately, and a survey of post-war national outlay and national income after the War emphasizes that our standard of living will, and always must be, dependent on the maintenance of high productive efficiency. Discussing, in conclusion, finance and politics, the Tory Reform Committee does not believe that the measures of social reform which it has championed are beyond the taxable or economic capacity of the nation to bear, or beyond the willingness of the majority of individuals to provide by personal effort and sacrifice. It is well aware, however, that such 
limits exist, and they have for the time being been nearly approached; the Committee urges that the time has come to concentrate upon increasing the national income in the cause of social progress by every means and particularly by increased industrial eificiency. The pamphlet is an honest attempt at clear thinking and is a striking contrast to recent pronouncements regarding the adoption of a fortyhour week, which have omitted all indication of the price which has to be paid for adopting any such objective in our immediate post-war programme.

\section{Geographical Research in China}

As account of geographic research in China by Prof. Chi-Yun Chang (Ann. Assoc. Amer. Geog., 39, No. 1, March 1944) contains a record of a great deal of valuable work, much of which, under present conditions, may have escaped notice in Great Britain. Large numbers of topographical maps have been printed recently including a bathyorographical one of the whole of China on a scale of one to three million. A beginning of land utilization maps has been made, and a generalized soil map has been published. The Research Institute of Meteorology of the Chinese Academy has been investigating the problems of winds and rainfall over China with the result that the old conception of the south-east monsoon being chiefly responsible for the rainfall has been displaced in favour of cyclonic influences being mainly responsible: most of the rainfall appears to be associated with cold fronts. In historical and other aspects of human geography research has also been active. The report also notes the development of geographical education, probably temporarily interrupted, the foundation of the Chinese Institute of Geography and a number of geographical periodicals.

\section{Russian Papers on Pure and Applied Mathematics}

A NUMBER of Russian publications containing papers on pure and applied mathematics have been received, and most of them have at least an abstract in English, French, or German. In a few cases the papers are entirely in English. They include numbers of the Bulletin of the U.S.S.R. Academy of Sciences (Mathematical Series) (1941-43), the Moscow Receuil Mathématique (1942-3), Applied Mathematics and Mechanics (1943), Engineering Review (1943), and Comptes Rendus (1943). It is difficult to describe the mathematical contributions in a limited space ; they deal with trigonometrical series, the theory of functions and other topics such as are treated in our own mathernatical journals. As regards the engineering papers, attention may be directed particularly to the papers by Glagolev, Popov and Proktor on "The Mechanical Properties of Rubber"' Erokhin, Nikolaeva and Oghibalov on "Dynamic Brittleness of Metals"; Kasparov on "Distribution of Pressure on the Blades of a Hydroturbine" (all in Eng. Rev., 2 ; 1943) and to those by Astrov, Levin, Pavlov, and Khristianovitch on "The Design of the Laval Nozzles", Pugachev on "The General Problem of Exterior Ballistics for Aviation Bombs", Cetajev on "The Sufficient Conditions of the Stability of a Rotating Motion of a Projectile", Banin on "Approximate Conformal Transformations applied to the Plane-Parallel Flow past an Arbitrary Shape" (all in App. Math. and Mech., 7 ; 1943).

\section{Identification of Timbers}

Mr. Alexander L. Howard's "Studies of the Identification of Timbers" was reviewed in Nature of November 7, 1942. It is interesting now to record the appearance of a supplement containing 153 photomicrographs of different kinds of wood ("Supplement to Studies of the Identification of Timbers." By Alexander L. Howard. Pp. 19. London: Macmillan and Co., Ltd., 1943. 5s. net), and one cannot but admire the author's continued enterprise in producing a supplement to a book of this kind in time of war, and promising yet another in the near future. Attention was directed, when reviewing the original volume, to certain features of the book which limit its practical value. Since the supplement has been prepared along precisely the same lines, it will be found to present similar difficulties when used for the practical identification of timbers.

\section{Announcerrents}

WE regret to announce the death of Sir John Ledingham, C.M.G., F.R.S., formerly director of the Lister Institute, London, on October 4, aged sixty-nine.

The Council of the Royal Aeronautical Society has awarded the Society's Gold Medal to Air Commodore Frank Whittle, for his work on jet propulsion. This award is the highest the Council can make, and has been made on only seven previous occasions, the recipients being as follows: Wright Brothers (1909), Prof. O. Chanute (1910), Prof. G. H. Bryan and Mr. E. T. Busk (1915), Dr. F. W. Lanchester (1926), Prof. L. Prandtl (1927), Sir Richard Glazebrook (1933) and Senor Juan de la Cierva (posthumously, 1937).

THE following appointments have been made in the University of London: Mr. H. Berry, to be professor of pharmaceutics; Dr. W. H. Linnell, to be professor of pharmaceutical chemistry. Both appointments are tenable at the College of the Pharmaceutical Society.

THE National Council for Mental Health has arranged a course of ten lectures, by various authorities, on "The Psychology of Frustration and Fulfilment in Adult Life". The lectures, which are addressed specially to those with social and educational interests, are being given on Tuesdays at 5.30 p.m. at the Caxton Hall, London, S.W.1, and began on October 3. A parallel course is being given on Wednesdays at 5.30 p.m. at the Friends' Meeting House, Bull Street, Birmingham. Tickets for the course can be obtained, price $£ 1$, from the Secretary, National Council for Mental Hygiene, 39 Queen Anne Street, London, W.1, or single tickets, 3s. $6 d$., at the door before each lecture.

ThE Selection Committee of the Harrison Memorial Fund, consisting of the presidents of the Chemical Society, the Royal Institute of Chemistry, the Society of Chemical Industry and the Pharmaceutical Society, will make an award of the Harrison Memorial Prize in December 1944. The Prize, not exceeding $£ 150$, is open to a chemist of either sex, being a natural born British subject and not at the time more than thirty years of age, for original investigations in chemistry carried out and published during the past five years. Further particulars can be obtained from the President, Chemical Society, Burlington House, Piccadilly, W.1. Applications must be received not later than December 1, 1944. 